
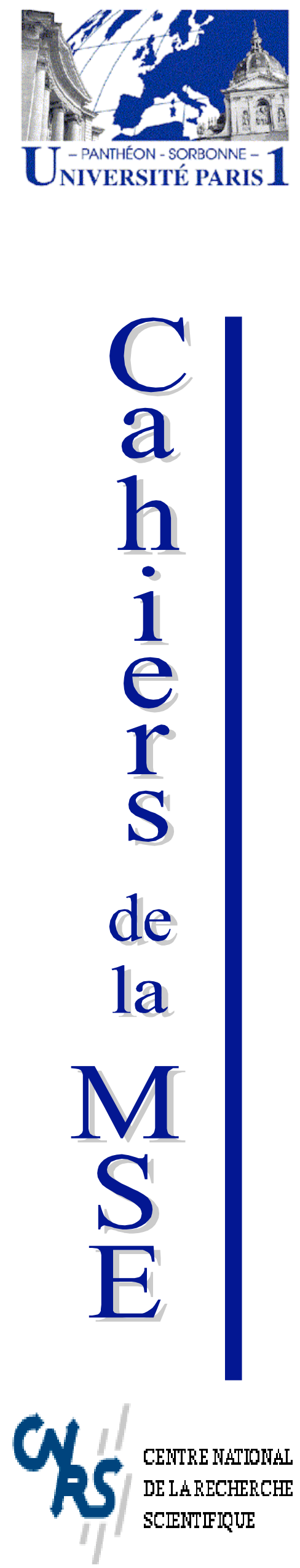

CENTRE NATIONAL

DE LARECHERCHE

SCIENTIFIQUE

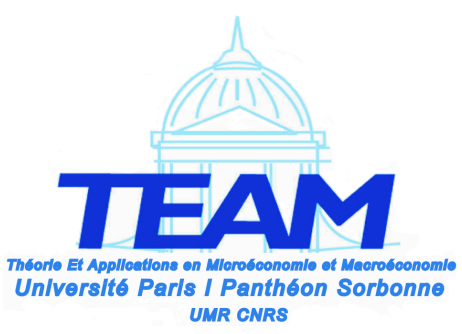

Bilateral donor's interest vs. recipients' development motives in aid allocation : do all donors behave the same?

Jean-Claude BERTHELEMY, TEAM

2005.01 


\title{
Bilateral donors' interest vs. recipients' development motives in aid allocation: do all donors behave the same?
}

\author{
Jean-Claude Berthélemy* \\ University Paris 1 Panthéon Sorbonne, TEAM - CNRS \\ 106-112 Bd de l'Hôpital, 75647 Paris Cedex 13, France \\ berthele@univ-paris1.fr
}

January 2005

Paper presented at the HWWA conference on the Political Economy of Aid, Hamburg, 9-11 December 2004. 


\section{Résumé}

Ce papier propose une évaluation empirique d'ensemble des motivations de l'aide publique au développement accordée par des pays riches aux pays en voie de développement, telles qu'elles sont révélées par leurs comportements d'allocation de l'aide. Ces comportements résultent d'une combinaison de la recherche de l'intérêt propre des donateurs et d'objectifs de développement plus altruistes. Pour mettre en œuvre cette analyse, on utilise un ensemble de données de panel tridimensionnel, combinant les donateurs, les destinataires et la dimension temporelle. Ces données révèlent beaucoup d'hétérogénéité dans les comportements des donateurs. Grâce à l'étendue de cet ensemble de données, des tests appropriés des différences de paramètres entre les donateurs peuvent être réalisés. Particulièrement, ces tests fournissent un moyen de comparer le degré d'altruisme des différents donateurs.

Mots-clés: distribution internationale de l'aide, altruisme classification JEL: F35; C23; C24

\section{Abstract}

In this paper, I provide an overall empirical assessment of the motivations of official development assistance granted by rich countries to developing countries, as they are revealed by their aid allocation behaviours. Such behaviours result from a combination of self-interest purposes and of more altruistic development objectives. To perform this analysis, I use a three-dimensional panel dataset, combining the donor, recipient and time dimensions. Such data show a lot of heterogeneity in donor behaviours. Thanks to the width of this dataset, I can properly test differences of parameters among donors. In particular, these tests provide a way to compare the degree of altruism of the different donors.

JEL classification: F35; C23; C24

Keywords: International aid allocation, Altruism 


\section{1- Introduction}

The motives of development assistance have been long disputed in the development finance literature. Discussions have been focused on the opposition between egoistic behaviours, linking aid to the self-interest of the donor, and altruistic behaviours, relating it to recipient needs and merits. The recent debate on aid efficiency has created a renewed interest in this question. Following Burnside and Dollar (2000), concerns about aid efficiency have been in particular related to some factual evidence suggesting that aid allocation decisions would be based on objectives quite different from development promotion. For instance, Burnside and Dollar relate aid inefficiency to biases of bilateral aid allocation in favour of Franc Zone members, Egypt and Central America, which result from post-colonialist and geopolitical motives.

The aid allocation literature has converged toward models in which both egoistic and altruistic behaviours are combined in aid allocation decisions. This conclusion must be however qualified by a comparative approach, given that not all donors do not implement the same policies or have the same objectives, in spite of coordination by the Development Assistance Committee (DAC) of the OECD. An attempt in this direction has been already proposed by Alesina and Dollar (2000). However, although they provide different parameter estimations for the various donors, Alesina and Dollar do not perform tests of differences among donors. Berthélemy and Tichit (2004), using a different econometric approach, have provided to my knowledge the first proper attempt at testing differences among donor behaviours, using a very large dataset built by the DAC on geographic distribution of bilateral assistance. One methodological and practical difficulty that needs to be overcome here is to combine properly the approaches that have been developed to correct potential biases that occur from sample selection (the dependent variable being a censored variable) and the treatment of fixed effects that inevitably arise when one uses a large dataset combining two geographical dimensions (donors and recipients) and a time dimension. Berthélemy and Tichit used for that matter a random-effect Tobit model. In the present paper, I use the same dataset, but I explore a different econometric approach - closer to the one proposed by Burnside and Dollar -, based on a two-part model, which is practically more manageable, and more commonly used in the aid allocation literature. 
After a brief literature review in section 2, I discuss in section 3 the econometric framework, and I describe in section 4 the explanatory variables that I am going to use to test the selfinterest of donor motives and the recipient needs and merits motives in bilateral assistance. In section 5, I provide results of estimation of the behaviour of the average donor. Tests of differences of parameters among donors are reported in section 6 , together with an attempt at clustering the donors in different groups according to their degree of altruism. Section 7 concludes.

\section{2- Literature review}

Several papers have addressed the issue of allocation of bilateral aid to recipient countries. The interest in this topic began in the mid-1950s with Behrman (1955/6). Broadly speaking, up to the works of Dudley and Montmarquette (1976) and of McKinley and Little (1977, 1978a, 1978b, 1979) the analysis was rather anecdotal and based on simple empirical observation. Those authors have introduced econometrics in the debate on the factors influencing aid allocation and have structured the discussion around two alternative determinants: the "recipient need" and the "donor interest". However, whenever all of these variables are relevant for the explanation of aid allocation, one needs to introduce them all together in the same model to avoid biases due to omitted variables. This gave rise to a generation of so-called "hybrid" models. The present paper belongs to this family. Econometric methods have also improved over time, but the literature has mainly concentrated so far on one donor for a given period of time (recently using panel data) 1 , or several donors in cross section. ${ }^{2}$ The present paper, instead, utilises all the dimensions of available data.

Moreover, many papers do not take account of the censored nature of the aid variable. Yet, running ordinary least squares on the amount of aid allocated may generate biases. Indeed, as first documented by Dudley and Montmarquette (1976), the process of aid allocation entails two kinds of questions: whether to allocate some aid to a given potential recipient and, in case

1 Cf. in particular Tarp et al. (1998).

2 Cf. Alesina and Dollar (2000). 
of a positive answer, how much aid give to this recipient. To evaluate such a process empirically, three estimation methods are available, which have similar, but not identical, econometric properties: using a two-part model, or a Heckman procedure, or running a Tobit regression.

McGillivray and Oczkowski $(1991,1992)$ use a two-part model to estimate the Australian and British allocation of aid. Gang and Lehman (1990) run a Tobit model to study the allocation of American aid to Latin American countries. Tarp et al. (1998) apply the Heckman method to estimate a panel model of bilateral Danish aid allocation. Trumbull and Wall (1994) utilize the same procedure extended to multiple donors. They examine total official development aid (bilateral and multilateral, whoever the donor) to 86 recipient countries covering the 1984-89 period. They introduce both time and recipient fixed effects. To our knowledge, this is the only paper on several donors' aid allocation using panel data and correcting for the censored nature of the dependent variable. The analysis is nevertheless limited to a short period of time and to a two-dimensional (recipient-year) panel, as the dependent variable is the total amount of aid received from the whole donor community. This aggregation is valid only under the assumption that all donors are homogeneous, which seems to be wrong. As a matter of fact, Alesina and Dollar (2000) have estimated aid allocation equation for different donors, using aid allocation data aggregated over 5 five-year periods, and have found that donor behaviours differed significantly from each other. Testing the validity of this conclusion will be precisely the main purpose of the present paper.

\section{3- Modelling framework}

I use in this paper the largest and the most exhaustive available dataset for the 1980 and 1990 decades. It covers 137 recipient countries and the 22 donors of the Development Assistance Committee (DAC) of the OECD. 3 For each of the years from 1980 to 1999, I observe aid commitments received by each recipient from each DAC member. This means that I deal here with a three-dimensional (year $\mathrm{x}$ donor $\mathrm{x}$ recipient) panel dataset, of potentially close to 60,000 observations. Of course, the number of observations will depend on the availability of

\footnotetext{
3 The present analysis is restricted to so-called "part I" countries, excluding transition economies and relatively rich recipients.
} 
explanatory variables. This availability being taken into account, I have still approximately 36,000 observations.

I choose aid commitments rather than disbursements, because, as documented by McGillivray and White (1993), this variable better reflects the donor decisions. Indeed, donors have more control on their commitments, compared to their disbursements, which depend in part on the recipients' willingness and administrative capacity to get the money. In order to neutralize the effect of inflation, these flows are converted into US dollars per capita at 1985 prices, using the OECD GDP deflator index as a proxy for world inflation.

An important step is to choose an appropriate specification and method of estimation of the model aimed at describing the aid allocation behaviour. In the previous literature, the specification and method of estimation of aid allocation equations has been debated at length. Different issues at are stake.

The principal issue is that we deal with a censored variable, given that aid commitment cannot be negative. This implies that there is possibly a selection bias if this feature is not taken into account. There are three different ways of correcting the selection bias:

The fist one is a two-part model: in a first step, a Probit model determines the probability of receiving assistance (selection equation), and in a second, a linear model explaining, based only on strictly positive observations, explains aid commitments (allocation equation).

$P\left(Y_{i j t}>0\right)=F\left(c Z_{i j t}+v_{i j t}\right)$

$Y_{i j t}=b X_{i j t}+u_{i j t}$

Where $i$ stands for the donor, $j$ for the recipient and $t$ for the year; $u$ and $v$ are independent and normally distributed error terms, and

$Y$ is the dependent variable, i.e. the amount of aid commitment per capita (expressed here in logarithmic form in the allocation equation, but of course in natural form in the selection equation)

$Z$ and $X$ are explanatory variables for the selection equation and the allocation equation $b$ and $c$ are vectors of parameters

$F($.) stands for the cumulative distribution function 
In this procedure, the choice of a recipient and the amount of aid thereafter allocated to this country are supposed independent from each other. This method suffers from the risk of introducing a selection bias in the second step, since the fact that a country receives strictly positive aid commitments is not independent from the factors that may influence its selection as recipient.

The second possible approach is the Heckman's method: the procedure is the same as for the two-part model, except that $u$ and $v$ are not assumed independent. It can be implemented either in a two-step method, or in a one-step maximum likelihood procedure. In the two-step method, one first estimates the Probit selection equation. Then in a second step, the inverse Mill's ratio obtained from the first step is introduced together with explanatory variables, in order to correct the selection bias due to the endogenous nature of the allocation of the selection process.

$P\left(Y_{i j t}>0\right)=F\left(c Z_{i j t}+v_{i j t}\right)$

$Y_{i j t}=b X_{i j t}+\rho \sigma f\left(c Z_{i j t}+v_{i j t}\right) / F\left(c Z_{i j t}+v_{i j t}\right)+u_{i j t}$

Where $u$ and $v$ are normally distributed error terms, with $\operatorname{cov}(u, v)=\rho$, and $f$ stands for the partial distribution function and $\sigma$ for the variance of $u .4$

In the one-step Heckman's estimation procedure, the specification is similar to the previous one, but all parameters, including the correlation between the error terms of the selection and allocation equations are estimated in one single maximum-likelihood procedure.

$$
\begin{aligned}
& P\left(Y_{i j t}>0\right)=F\left(c Z_{i j t}+v_{i j t}\right) \\
& Y_{i j t}=b X_{i j t}+u_{i j t}
\end{aligned}
$$

Where $u$ and $v$ are normally distributed error terms, with $\operatorname{cov}(u, v)=\rho$.

The third approach is a Tobit model, which estimates the aid commitments in only one-step, taking directly into account its censored nature. The difference with the Heckman's method is

\footnotetext{
4 The invers Mill's ratio is the second term in the right hand side of the allocation equation.
} 
that the exogenous variables are supposed to have the same impact on the probability of receiving aid and on the amount of aid allocated thereafter: aid received is described as the maximum of zero and of a linear combination of the explanatory variables.

$Y_{i j t}=\operatorname{Max}\left(b X_{i j t}+u_{i j t}, 0\right)$

In Berthélemy and Tichit (2004), this last approach was used. Here, with the same database, I use the Heckman and the two-part approaches. Although the results are not qualitatively very different, and therefore confirm to a large extent Berthélemy and Tichit results, this method has here two merits:

- First of all, it permits using a log-linear specification for the aid allocation equation, provided that the logarithm of zeros (the censored observations) are treated properly as unobservable variables. This introduces more flexibility and allows for an easiest interpretation of parameters. For instance, estimates will not change whether the equation is estimated on an aid per capita basis or on an aid volume basis, once the size of population of the recipients has been introduced in the right-hand side of the equation. This constitutes the most convenient answer to a recurrent - but not much productive - debate in the aid allocation literature on whether aid allocation behaviours are decided on a volume basis or on a per-capita basis (on this debate, see McGillivray and Oczkowski, 1992, and Neumayer, 2003).

- Second, the Tobit procedure, with a very large database, is hardly manageable with a large number of explanatory variables, for computational reasons. Here, I have been able to introduce a much larger number of explanatory variables than in Berthélemy and Tichit. This constitutes an essential advantage when one tries to compare different donor behaviours and to test their differences, because such tests necessarily involve multiplying the number of parameters to be estimated by the number of donors, which leads to a very large number of explanatory variables.

Another issue concerns the possible introduction of fixed effects. With a very large database, with a lot of heterogeneity among recipients, it is necessary to take account of recipient specificities that would not be taken into account by the explanatory variables. However, in practice, estimates are not consistent when fixed effects are introduced in a Probit selection 
model or in a Tobit model. There is therefore no perfectly satisfying method available. To deal with this issue, I have used the following procedure:

- (1) I have checked that the allocation equation in the Heckman procedure is qualitatively not very different from the one obtained in the second step of the two-part method, which consists simply in a linear estimation based on observations for which aid commitment is strictly positive. This comes from a weak correlation between the error term of the selection and allocation equations. Therefore, in this particular case, the properties of the selection equation and of its error term do not matter much for the estimation of the determinants of aid allocation. This result is similar to the one obtained with a smaller dataset by Alesina and Dollar (2000), who concluded that a linear estimation on strictly positive observations was for all practical purposes as good as a Heckman estimation.

- (2) I have introduced fixed effects in the single equation for aid allocation. Introducing such fixed effects does change a few results significantly, proving that taking account of fixed effects matters for the end result.

- (3) For double-checking, I have introduced recipient dummy variables in the Heckman procedure. Unsurprisingly, this has a major (and non-interpretable) impact on parameters estimated in the selection equation. However, the aid allocation equation is very similar to the one estimated in step (2), confirming the initial conclusion that in this particular case correcting the potential selection bias does not matter very much. I have therefore kept estimates obtained in step (2).

\section{4- Discussion of explanatory variables}

As indicated earlier, a proper description of bilateral aid allocation behaviours requires combining both self-interest of donor variables and variables that take into account the recipient needs and merits. 5

5 The definition of all variables and their sources are provided in Appendix 1. 
The self-interest of donor argument may be linked to several objectives pursued by the donors. One of them is geopolitical. The usual hypothesis in the previous literature is that providing aid to a recipient may influence the recipient's attitude in favour of the donor. In this context, it is usually assumed that a donor will provide assistance to recipients who are like-minded, or at any rate who are potential political allies. Alesina and Dollar (2000) use data on votes at the UN to measure such a political alliance effect. However, political alliance may be a result as well as a determinant of aid allocation. Another possibility is to link this political alliance factor to the colonial past of the donors. A related argument suggests a link to internal politics: Lahiri and Raimondos-Møller (2000) propose a theoretical model in which the lobbying by ethnic groups may influence aid pattern. They illustrate this analysis with data showing the significant amounts of aid given by the United Kingdom to India, the United States to Israel, Germany to Turkey and France to Cameroon. They conclude that, assuming that there is a positive correlation between ethnic composition and the colonial history of a donor country, this may explain why former colonies are usually major recipients of official development assistance from their former colonial rulers.

In this paper, I use, to catch these effects, a combination of dummy variables for former colonial ties and for other broad geopolitical interests of the donors:

- Bilateral dummy variables for former colonies of Belgium, France, Portugal, Spain and the United Kingdom.

- A bilateral dummy variable for the couple United States-Egypt, because Egypt has received large amounts of assistance from the United States since its peace accords with Israel. Would Israel be in our database, we would need obviously to introduce a similar dummy variable for its link with the United States, but Israel is not anymore a developing country.

- A bilateral dummy variable catching the close ties that exist between the United States and Latin American countries.

- A bilateral dummy variable catching the geopolitical interest of Japan in assisting Asian developing countries.

I have also tested whether European Union's members were giving more assistance across the board to ACP countries (Associated states from Africa, the Caribbean and the Pacific Ocean), in favour of which the European Community has established from 1963 a preferential 
treatment regime, but this variable is never significant in my regressions. As shown by Grilli and Riess (1992), there is possibly a bias in the aid budget managed by the European Commission itself towards ACPs, but, according to my estimations, this bias does not show up in bilateral aid patterns, when all other factors are controlled.

Aid may be used also to deepen commercial linkages with a recipient, and not only political alliances. Not all donors have strong geopolitical interests, but all of them have trade interests. A donor's foreign assistance policy based on its self-interest will typically be biased toward countries who tend naturally to have more trade with it. This is after all the clear motive of tied aid, which persists in spite of continuous efforts from the OECD/DAC to keep it under control. Therefore, following Berthélemy and Tichit (2004), I have also introduced commercial interest motives, as measured by the flow of bilateral trade (imports+exports) with the recipient country, expressed as a percentage of the donor GDP. There might be a simultaneity bias when aid is tied, since more tied aid will imply more imports from the donor. However, the risk is limited since I am working on aid commitment flows, and aid disbursements usually lag behind commitments, particularly for project aid, which require building new equipment. In order to be of the safe side, I have lagged this variable.

As a complement, it is useful to consider financial motives, particularly for my period of observation, during which a large number of recipients has been affected by a debt crisis. In the debt crisis literature (see, e.g., Birdsall, Claessens and Diwan, 2003), this is known as the "defensive lending" argument. Donors could be locked in a "debt game", in which they have to provide new resources to highly indebted countries simply to avoid that these debtors fall in arrear. However, it is not possible to test this argument in a truly bilateral way that would take account of debt owed by each recipient to each specific donor, for two reasons: first, theoretically speaking, a donor cannot protect its own financial interest alone through defensive lending, because refinancing and other financial relief mechanisms are usually subjected to rather strict burden-sharing rules, for instance under the auspices of the Paris Club; second, bilateral debt data are hardly accessible, when they exist. Nevertheless, I will introduce a debt burden variable, defined as the ratio of net present value of debt over export, as an explanatory variable in my aid allocation equations. This variable can be interpreted to some extent as a self-interest variable. There is however some irreducible ambiguity in this interpretation, since one could also argue that a heavy debt burden increases the needs of the debtor, which could motivate donor assistance. 
Let me turn now to the development motives of aid. These development motives are of course, according to most donor statements, the actual purpose of their assistance programs. Such motives can be captured by the introduction of two different categories of variables. A first category is based on the argument saying that aid is granted to the neediest countries, for the sake of poverty alleviation. A second category takes into account the issue of aid efficiency: if the objective is poverty alleviation, aid should be given to recipients where it can have an impact on poverty, which may depend on the quality of economic policies and on the governance of these countries.

The most straightforward indicator of beneficiary needs is income per capita, measured at international prices (in purchasing power parity terms). If aid is to be allocated based on recipient needs, the poorer countries should receive more, and the richer countries less.

The quality of development policies is more difficult to measure. I have tried several policy variables similar to those introduced by Burnside and Dollar, such as openness, government deficit and inflation. None of these variables was significant. However, the observable outcome of these policies, measured by real GDP growth rates, is positively linked to aid allocation. In order to avoid simultaneity bias, I have introduced this variable with a lag, so that the estimation can clearly be interpreted as showing the impact of past growth on new aid allocation. I have also tried social outcome variables, namely life expectancy at birth, child mortality, literacy rate and school enrolment ratios. Such variables are to some extent correlated with aid allocation, but none of these variables showed any robust correlation with aid allocation, possibly because their introduction reduces drastically the number of available observations, for lack of complete data.

Concerning governance, I have used the civil liberty and political freedom evaluation provided by Freedom House. This variable is a multinomial qualitative variable, which takes values from 1 (highest quality of democracy) to 7 (lowest quality of democracy). Introducing this variable directly in the regression would be awkward, since there is no reason, for instance, to assume that the marginal impact of a shift of this variable from 1 to 2 would be the same as the impact of a shift from 2 to 3, or half the impact of a shift from 1 to 3 . The only proper treatment of this variable is to decompose it into as many dichotomic dummy variables as it has occurrences, and to introduce each and every of these dummy variables in the 
regression. In principle, since I use the average of two indices (civil liberty, and political freedom), each with seven occurrences, I would have to deal with 13 occurrences. However, the differences of parameter estimates on these 13 dummy variables are not all significant. Tests of differences of such parameters suggest actually that countries can be regrouped into only two categories: those that have an index equal or below 4, and the others. This amounts to simply define a democracy/non-democracy dummy variable, based on this threshold.

I have also attempted to introduce some other variables linked to governance. The first one concerns the occurrence of conflicts, be they internal or interstate. I have used for that matter the database built by PRIO (International Peace Research Institute of Oslo), which defines 4 categories of conflicts: extrastate (colonial conflicts - which is not relevant in our case), interstate, internal and internationalized internal. For each category, PRIO defines 3 levels of intensity, from minor conflict to actual war. I have introduced such information using the same methodology as for the Freedom House index. The end result is the introduction of two dummy variables: one corresponding to non-minor internal conflicts, and the other corresponding to non-minor interstate conflicts. In the final results, these two variables will be merged into only one single conflict dummy variable.

One could also try to introduce, as indicator of governance, a corruption index, as proposed by Alesina and Weder (2002). However, long time series on corruption are not available for a large number of recipient countries, and, as a matter of fact, the corruption indicator used by Alesina and Weder is correlated with aid allocation only in a small number of cases, suggesting that this is not a universal determinant of aid.

Another, more indirect, variable that can be used to test whether aid is granted to recipients considered as well-governed is the per capita amount of assistance that they receive from multilateral donors. Multilateral assistance acts very often as a catalyst of bilateral aid, and such multilateral assistance is conditional on the implementation of structural adjustment and reform programs. It may therefore be assumed that it is used by the bilateral donors as a signal that the recipient is committed to put to good use the external resources that it receives.

In the same spirit, I have also entered the total aid commitments (per capita) provided by other bilateral donors. This variable, utilised for instance by Tarp et al. (1998), is introduced to test whether a donor reacts on average positively or negatively to aid allocations decided by other 
donors. In the first case, the assistance of other donors can be considered as complementary to one's assistance. However, the aid granted by other donors could also be considered as a substitute, rather than a complement, of one's assistance - notably in the case of egoist donors -, in which case the correlation between a particular donor's aid commitment and the other donors' aid would be negative.

Finally, I have attempted to introduce data on military expenditure, as a share of GDP, available since 1988 from SIPRI (Stockholm International Peace Research Institute). One could argue that "excessive" military expenditure should trigger a reduction of foreign assistance, because it would imply a high risk of utilization of this assistance for nondevelopmental purposes. However, this variable was never significant.

The above-described explanatory variables are complemented by two auxiliary variables: the recipient population and each donor total allocation of bilateral aid. Introducing these two variables provides our framework the necessary flexibility to discuss aid allocation decisions alternatively, from a recipient perspective, in terms of aid per capita that a recipient may expect from donors or, from a donor perspective, in terms of sharing of a given aid budget among various potential recipients.

Introducing the population of the recipient in the list of explanatory variables is necessary because the size of the recipient is not neutral, as initially shown by Dudley and Montmarquette: there are administrative costs, which are not proportional to the amount of aid granted. Due to the presence of sort of fixed costs in aid administration, per capita aid granted to a given recipient may depend positively or negatively on its population, depending on the elasticity of administrative costs with respect to the amount of aid granted, and on the elasticity of the expected aid impact with respect to the recipient's population (see Dudley and Montmarquette, 1986). Empirically, one usually observes that small countries receive more assistance per capita then large countries.

Introducing the total amount of aid granted by the donor on the year of observation provides a way to take into account the fact that some donors have larger aid budgets than others, and that such aid budgets fluctuate over time. I do not attempt here to explain the size of donors' aid budgets, which is usually a political decision made prior to aid allocation per se. 


\section{5- The average aid allocation behaviour}

Results of estimation of the aid allocation equation are reported in Table 1. First, this Table provides estimates obtained from a standard maximum-likelihood Heckman procedure. Similar results (not reported here) were obtained using the two-step Heckman method. Estimation results suggest that there is not much correlation between the error term of the selection equation and of the allocation equation. This is shown in particular in column (2), where the largest possible number of observations was used to estimate the selection equation. In this estimation, all explanatory variables are introduced in the selection equation in levels, instead of in logarithms. Given than a number of bilateral trade flows, with small developing countries, are equal to zero, this specification saves some 6,400 observations (most of which being observations in which the potential recipient is in fact not selected).

[Table 1 about here]

I therefore proceeded, as explained in section 3, to estimations of aid allocation equations ignoring the potential correlation with the selection process. Comparing column (3) with columns (1) and (2) suggests that neither the parameter estimates nor their significance change much from one specification to the other. Moreover, it appears that all variables of interest are significant. As expected, aid allocation received by a recipient $j$ from a donor $i$ is positively correlated with the bilateral trade intensity between $i$ and $j$ and with the different bilateral geopolitical and post-colonial dummy variables. In addition, a recipient receives more assistance when it is poorer and more indebted, but also when it is more democratic and less affected by interstate conflicts, and when it has grown faster previously. This suggests that the donors take account, in their allocation decisions, of both recipient needs and recipient merits. However, internal and interstate conflicts seem to play opposite roles. The positive role observed for internal conflicts is consistent with Chauvet (2003), who finds with other data that aid allocation depends positively on violent political instability, but is difficult to interpret here in view of the opposite result found for interstate conflicts. Finally, according to these estimates, the elasticity of the aid assistance that a recipient receives from a donor, with respect to the total bilateral aid allocated by this donor, is close to 1 ; and the assistance received from a given donor increases with the assistance received from other donors and from the multilaterals. 
Of course, there is a risk that the previous explanatory variables only partially describe the recipient characteristics, in particular the quality of their institutions. Introducing fixed-effects may correct for possible biases due to such missing institutional explanatory variables 6 . This is done in column (4). This estimation leads to two major changes in parameters: the interstate conflict dummy variable has now a negative, instead of positive, impact, and there is substitution instead of complementarity between a donor's aid allocation and the other donors' aid allocation. Column (5) reports similar results, where I assume that interstate and internal conflict effects on aid allocation have the same magnitude, an assumption that is consistent with estimates reported in column (4). This model reported in column (5), where all parameters are estimated with a $1 \%$ significance level, will be my benchmark for comparing the various donor behaviours in section 6 .

Before going to this discussion, I have performed some further checks of robustness of my results in two directions. First, I have checked that parameters do not change much from the 1980s to the 1990s. The principal changes between the two decades are a significant reduction of the impact of the trade variable, which remains however significantly positive, and a reduction of the impact of the multilateral aid variable. The former result is consistent with a general tendency to refrain aid tying, which suggests a reduction of aid giving for commercial motives. The latter may be explained by the major role played by the multilateral institutions in the resolution of the debt crisis of the 1980s. Second, I have checked that results are very similar if one considers only grant commitments, instead of total official development assistance commitments. Results are provided in Appendix 2.

It is also relevant to explore the properties of the selection equation, which should be in principle consistent with the aid allocation equation, even though in the end they are estimated separately. Here comes a further technical difficulty, as indicated previously: a Probit equation cannot be estimated with fixed-effects, for the reason that estimates of the fixed effect would not be consistent. This leads me to consider only a standard Probit estimation, and a random-effect Probit. Both methods lead to very similar results. In both methods, a further technical difficulty comes from the fact that the bilateral dummy variables for former

6 Similar results (not reported) are obtained with a random-effect method, but the Hausman test is in favour of fixed effects. 
French and Belgium colonies and for the Japan-Asia relationship perfectly predict selection. Therefore, the parameters for such dummy variables cannot be properly estimated. Consequently, the Probit equations are estimated without these variables, and the corresponding observations are dropped. Moreover, the parameters estimated for the bilateral dummy variables concerning the former Portuguese and Spanish colonies and concerning the United States - Latin America relationship have the wrong sign, as shown in column (1), Table 2. These variables are thereafter dropped, as reported in columns (2) and (3). Most of the remaining variables are very significant and have signs consistent with those found for the allocation equation. A potential recipient $j$ has a higher probability of being selected by a donor $i$ if it trades more with it, and if it is poorer, more indebted, more democratic, growing faster and if it receives more assistance from the multilaterals and from other bilaterals. The impact of conflicts is however unclear. Finally, size counts, given that larger countries tend to have a higher probability of being selected, and that a larger total aid budget of the considered donor increases also this probability.

[Table 2 about here]

When the same equation is estimated with a random-effect Probit method - column (3) - , the only visible change is that, consistently with what we observed for the aid allocation equation, the complementarity with other bilateral donors disappears.

In what follows, I will focus the analysis on the allocation equation, because, as just explained, the available data do not permit a proper estimation of a number of bilateral effects in the selection equation, such as the post-colonial French and Belgium links and the JapanAsia and United States-Latin America linkages. Therefore, a comparison of the selection behaviours of the various donors would lead only to partial results.

\section{6- Comparison among donors}

I start by testing that the parameters for a given donor $\alpha$ differ from parameters for other donors. I define a dummy variable $\mathrm{D}_{\alpha}(\mathrm{i})$

$D_{\alpha}(i)=1$ if $i=\alpha$, and $D_{\alpha}(i)=0$ otherwise 
Then I introduce new explanatory variables defined by interacting this donor dummy variable with all previous explanatory variables entered in the equation previously reported in Table 1, column (5). This defines the following model:

$$
Y_{i j t}=b X_{i j t}+b_{\alpha}^{\prime} D_{\alpha}(i) X_{i j t}+u_{i j t}
$$

This provides a direct test of differences of parameters, a sample of which (for the trade intensity variable) is reported in Table 3.

[Table 3 about here]

The overall result of these tests is that there are significant differences of parameters among donors, for virtually all donors. I have then tried to identify clusters of donors, defining groups of countries with relatively similar behavioural parameters. Given the wide variety of explanatory variables, there are many different possibilities of grouping donors. I have chosen to focus this exercise on the trade intensity variable, which best describes the differences of egoism among donors. This leads me to define three categories, or clusters:

1- The "altruistic" cluster: Donors who have a trade intensity parameter significantly lower that other donors: Austria, Denmark, Ireland, Netherlands, Norway and Switzerland;

2- The "moderately egoistic" cluster: Donors who have a trade intensity parameter nonsignificantly different from other donors: Belgium, Canada, Finland, Germany, Japan, New Zealand and United States;

3- The "egoistic" cluster: Donors who have a trade intensity parameter significantly higher than other donors: Australia, France, Italy and United Kingdom.

In this classification, I have left aside a few donors, for which the available data did not provide enough information to estimate properly a specific set of parameters for the aid allocation equation. Unsurprisingly, we find in this category small donors, and recent donors: Greece, Luxembourg, Portugal and Spain. Sweden belongs also to this group, for a purely statistical reason: although Sweden has been for a long time a major donor, for a number of 
years around the mid-1990s, the geographical distribution of most Swedish aid commitments is not identified in the DAC database, which prevents a proper estimation of the equation.

It should also be noted that, in the second cluster, the case of Japan is peculiar: the presence of the Japan-Asia dummy variable significantly reduces the estimate of its parameter for the trade intensity variable, simply because Japan and other Asian countries have major trade linkages. When this variable is dropped, the estimate of this parameter climbs to 0.40 , and it is significantly higher that the parameter observed for other donors. I have done a similar test in the case of the United States, using an estimation where I dropped the United States-Latin America dummy variable, but this time the difference of the United States' trade parameter with the other donors' trade parameter stays insignificant.

Finally, I explore whether the parameters of donors in a given cluster have some commonalities. To this end, I use estimates of a model where all parameters are supposed to be donor-specific, but are estimated jointly:

$Y_{i j t}=b_{i} X_{i j t}+u_{i j t}$

Estimating the 22 vectors of parameters jointly provides much better results than estimating them separately (as was done by Alesina and Dollar), simply because all recipient characteristics, and in particular the recipient fixed-effects, are common information for all donor allocation equations. Therefore, for instance, observing that Senegal gets more assistance than other comparable recipients from various donors is useful information to estimate the allocation parameters for each specific donor.

Such estimates are reported in Table 4 to 6 , together with the results of tests of difference with the parameters of other donors.

In the "altruistic" cluster (Table 4), Switzerland differs from the other "altruistic" donors, because it is actually the only one donor that we can truly consider as altruistic, in the sense that its parameter for the trade intensity variable is not significantly different from zero. All other donors in this cluster have significantly positive parameters for the trade intensity variable. Within this cluster, it is also interesting to note that all donors but Austria have a 
very large parameter (in absolute terms) for the GDP per capita of the recipient, which is consistent with a relatively altruistic behaviour: the needier the recipient, the more they help it. Austria behaves also differently from other donors concerning the role of democracy: the Austrian aid is the only one to be significantly and negatively correlated with democracy. Concerning the other parameters, commonalities among the "altruistic" donors are hardly found.

\section{[Table 4 about here]}

The second, "moderately egoistic", cluster is the largest one, and presumably the most heterogeneous, as shown in Table 5. It seems that all but Japan share a positive parameter for the impact of other donors' assistance, suggesting that they consider their assistance as a complement rather than as a substitute of the other donors' assistance. With the exception of the United States, they also tend to react more strongly to the occurrence of conflicts that the average donor. Conversely, the United States provide more assistance in conflict cases, rather than less assistance.

[Table 5 about here]

The third, "selfish", cluster is made of only four countries, but presents quite a substantial heterogeneity. All these countries consider the assistance of other donors as a substitute to their own assistance but, apart from that observation, these four donors have few common characteristics. France an Italy differ significantly from Australia and the United Kingdom, if only from the perspective of the "defensive lending" attitude: France and Italy have in common a very large parameter for the debt ratio, while for Australia and the United Kingdom this parameter is negative. Nevertheless, France has also a number of dissimilarities with Italy, if only because of the post-colonial nature of its foreign assistance policy. The same is true for a comparison between the United Kingdom and Australia.

[Table 6 about here] 


\section{7- Conclusion}

I have used in this paper the whole information available to describe the geographic allocation policies implemented by donors in the 1980s and the 1990s. Overall, this exercise shows that most donors but one behave in a rather egoistic way: not only those donors who have particular political linkages with some categories of recipient countries utilise their official development assistance to reinforce such ties, but also all donors but one target their assistance to the most significant trading partners. Nevertheless, most donors, and of course particularly the least egoistic ones, take some care of the neediest recipient countries. Moreover, on average, donors target recipients with better governance indicators, such as democracy or absence of violent conflicts. They also, on average, provide more assistance to recipients with higher growth performances. Finally, they act as complement of multilateral financial institutions. All these results suggest that, in spite of the egoism of donor policies, donors implement selectivity rules based on recipient needs and merits.

Such results are very robust and do not change much from one decade to the other, in spite of the end of the cold war. Of course, this stability is partly explained by the fact that I consider only developing countries here, and not aid to so-called "part II" countries in development assistance statistics.

There are nevertheless striking differences among donors. Switzerland, Ireland and the Nordic countries (with the relative exception of Finland, and possibly Sweden) have been so far much more altruistic than other donors are. Among the four biggest donors, three have been particularly egoistic (France, Japan and the United Kingdom); the fourth one, the United States, targets relatively less its commercial self-interest, but utilises its assistance policy for political motives, as shown by the big bias of its aid to Egypt, and as suggested also by its significant assistance to conflict countries.

Finally, my list of relatively altruistic countries may be confirmed by some other information available on their development assistance policies. On average over the period of observation, Denmark, the Netherlands and Norway had the highest aid performances, with total aid to GDP ratio close to 0.9 percent. Ireland, who was initially a much poorer country that the others, had on average in the 1980s and the 1990s a relatively small aid budget, but channelled more that 50 percent of its assistance through multilateral aid, instead of through 
bilateral aid. Switzerland is yet a different case, with also relatively modest levels of aid budget ( 0.33 percent of GDP), and not much assistance channelled through multilaterals. However, in the case of Switzerland, such data should be interpreted cautiously, given that this country became member of the World Bank only in 1992, and of the United Nations only in 2002. Moreover, Switzerland has consistently offered untied aid to developing countries, unlike most other donors. Conversely, Australia, France, Italy and the United Kingdom, are known (together with Austria, Canada and the United States), for frequently tying their assistance. 


\section{References}

Alesina, A., and D. Dollar (2000). 'Who Gives Foreign Aid to Whom and Why?'. Journal of Economic Growth, 5: 33-63.

Alesina, A., and B. Weder (2002), 'Do Corrupt Governments Receive Less Foreign Aid?', American Economic Review, 92(4):1126-37

Behrman, J. N. L. (1955/6). 'Aid for Economic Development and the Objectives of the United States Foreign Economic Policy’. Economic Development and Cultural Change, 4.

Berthélemy, J.C., and A. Tichit (2004). 'Bilateral donors' aid allocation decisions - a threedimensional panel analysis', International Review of Economics and Finance, 13: 253-74

Birdsall, N., Claessens, S., and I. Diwan, 'and Policy Selectivity Forgone: Debt and Donor Behavior in Africa', World Bank Economic Review, 2003, 17(3): 409-36.

Burnside, C., and D. Dollar (2000), 'Aid, Policies and Growth'. American Economic Review, 90 (4): 847-68.

Chauvet, L. (2002), 'Socio-political instability and the allocation of international aid by donors', European Journal of Political Economy, 19:33-59.

Dudley, L., and C. Montmarquette (1976), 'A Model of the Supply of Bilateral Foreign Aid'. American Economic Review, 66 (1): 132-42.

Easterly, W., 2001, 'Growth Implosions, Debt Explosions, and My Aunt Marilyn: Do Growth Slowdowns Cause Public Debt Crises?', World Bank, Policy Research Working Paper 2531.

Gang, I. N., and J. A. Lehman (1990), 'New Directions or Not: USAID in Latin America'. World Development, 18 (5): 723-32.

Grilli, E., and M. Riess (1992), 'EC Aid to Associated Countries: Distribution and Determinants', Weltwirtschaftliches Archiv, 128(2):202-20. 
Lahiri, S. and P. Raimondos-Møller (2000), 'Lobbying by Ethnic Groups and Aid Allocation, Economic Journal, 110: C62-79.

McGillivray, M. (2002), ‘Modelling Foreign Aid Allocation’. Helsinki/ UNU/WIDER, mimeo.

McGillivray, M., and E. Oczkowski (1991), 'Modelling the Allocation of Australian Bilateral Aid: Two-part Sample Selection Approach'. Economic Record, 67 (197): 147-52.

McGillivray M., and E. Oczkowski (1992), 'A Two Part Sample Selection Model of British Bilateral Aid Allocation'. Applied Economics, 24: 1311-19.

McGillivray, M., and H. White (1993), 'Explanatory Studies of Aid Allocation Among Developing Countries: A Critical Survey'. Institute of Social Studies Working Paper No. 148. The Hague: Institute of Social Studies.

McKinley, R. D., and R. Little (1977), 'A Foreign Policy Model of US Bilateral Aid Allocation.' World Politics, 30 (1): 58-86.

McKinley, R. D., and R. Little (1978a), 'The French Aid Relationship: A Foreign Policy Model of Distribution of French Bilateral Aid, 1964-1970'. Development and Change, 9 (3): 459-78.

McKinley, R. D., and R. Little (1978b), 'A Foreign Policy Model of the Distribution of British Bilateral Aid, 1960-70'. British Journal of Political Science, 8 (3): 313-31.

McKinley, R. D., and R. Little (1979), 'The US Aid Relationship: A Test of the Recipient Need and the Donor Interest Model'. Political Studies, 27 (2): 236-50.

Neumayer, E. (2003), Explaining the Pattern of Aid Giving. London: Routledge.

Tarp, F., C. F. Bach, H. Hansen, and S. Baunsgaard (1998), 'Danish Aid Policy: Theory and Empirical Evidence'. Discussion Paper 98/06. Copenhagen: University of Copenhagen, Institute of Economics. 
Trumbull, W., and H. Wall (1994), 'Estimating Aid-Allocation Criteria with Panel Data'. The Economic Journal, 104: 876-82. 


\section{Appendix 1: List and sources of variables}

\begin{tabular}{|c|c|c|}
\hline Variable & Definition & Source \\
\hline ODA & $\begin{array}{l}\text { Real ODA (OA) Commitments divided by the } \\
\text { population of the recipient country, using the } \\
\text { OECD GDP deflator }\end{array}$ & $\begin{array}{l}\text { OECD Development Aid Committee } \\
\text { database (international development } \\
\text { statistics) and OECD national account } \\
\text { statistics }\end{array}$ \\
\hline $\begin{array}{l}\text { Total ODA of } \\
\text { donor }\end{array}$ & $\begin{array}{l}\text { Total real ODA of the donor (totalled over the } \\
137 \text { recipients) }\end{array}$ & Authors own calculation \\
\hline Oth. Donors ODA & $\begin{array}{l}\text { Total of ODA given by other donors to the } \\
\text { recipient country }\end{array}$ & Authors own calculation \\
\hline $\begin{array}{l}\text { Multilateral ODA } \\
\text { per cap }\end{array}$ & $\begin{array}{l}\text { Real ODA (OA) Commitments of multilateral } \\
\text { donors divided by the population of the recipient } \\
\text { country, using the OECD GDP deflator }\end{array}$ & $\begin{array}{l}\text { OECD Development Aid Committee } \\
\text { database (international development } \\
\text { statistics) and OECD national account } \\
\text { statistics }\end{array}$ \\
\hline GDP per cap & $\begin{array}{l}\text { Real GDP Per Capita in constant dollars } \\
\text { (international prices, base year 1985) of the } \\
\text { recipient countries }\end{array}$ & Penn World Tables \\
\hline Population & Population, total & $\begin{array}{l}\text { World Bank's World Development } \\
\text { Indicators }\end{array}$ \\
\hline Trade & $\begin{array}{l}\text { Sum of bilateral imports and exports (corrected } \\
\text { for the OECD inflation) in } \% \text { of donor's GDP }\end{array}$ & OECD trade database \\
\hline Growth & $\begin{array}{l}\text { GDP growth (annual \%) of the recipient lagged } \\
\text { one period }\end{array}$ & $\begin{array}{l}\text { World Bank's World Development } \\
\text { Indicators }\end{array}$ \\
\hline Global freedom & $\begin{array}{l}\text { Mean of civil liberties and political right } \\
\text { indexes, ranging from } 1 \text { (most free countries) to } \\
7 \text { (less free countries) }\end{array}$ & Freedom House website \\
\hline Interstate conflict & $\begin{array}{l}\text { Dummy variable for non-minor interstate } \\
\text { conflict }\end{array}$ & International Peace Research Institute, Oslo \\
\hline Internal conflict & $\begin{array}{l}\text { Dummy variable for non-minor interstate } \\
\text { conflict }\end{array}$ & International Peace Research Institute, Oslo \\
\hline $\begin{array}{l}\text { NPV of } \\
\text { debt/export }\end{array}$ & Ratio of net present value of debt over export & $\begin{array}{l}\text { Data provided by Bill Easterly - see } \\
\text { Easterly (2001) }\end{array}$ \\
\hline Global freedom & $\begin{array}{l}\text { Mean of civil liberties and political right } \\
\text { indexes, ranging from } 1 \text { (most free countries) to } \\
7 \text { (less free countries) }\end{array}$ & Freedom House website \\
\hline
\end{tabular}




\section{Appendix 2: Further robustness checks}

I report in Table 7 separate estimates for the 1990s and 1980s decades, together with a test of differences between the two decades. In spite of some significant differences, the estimates appear qualitatively very stable.

[Table 7 about here]

In Table 8, I report tests performed on grant instead of total official development assistance commitment. The former are certainly a much more homogeneous category than the latter, which are a combination of grants and loans characterised by various grant elements. Table shows relatively similar results. Here the 1990s and 1980s decade are more different from each other.

[Table 8 about here] 
Table 1: Allocation equation

\begin{tabular}{|c|c|c|c|c|c|c|c|c|c|c|c|c|}
\hline & Heck & $\begin{array}{r}(1) \\
\operatorname{man}\end{array}$ & Heckr & $\begin{array}{r}(2) \\
\text { man }\end{array}$ & $\begin{array}{r}\text { (3) } \\
\text { OLS }\end{array}$ & & Random ef & $\begin{array}{l}\text { (4) } \\
\text { fect }\end{array}$ & Fixed effe & $\begin{array}{r}(5) \\
\text { ects }\end{array}$ & Fixed eff & $\begin{array}{r}(6) \\
\text { ects }\end{array}$ \\
\hline In(GDP per cap) (lagged) & $\begin{array}{r}-0.626 \\
(5.65)\end{array}$ & $* \star *$ & $\begin{array}{r}-0.573 \\
(5.38)\end{array}$ & *** & $\begin{array}{r}-0.588 \\
(5.49)\end{array}$ & *** & $\begin{array}{r}-0.749 \\
(14.12)\end{array}$ & *** & $\begin{array}{r}-0.772 \\
(7.81)\end{array}$ & *** & $\begin{array}{r}-0.769 \\
(7.78)\end{array}$ & $* * *$ \\
\hline In(population) & $\begin{array}{r}-0.467 \\
(7.35)\end{array}$ & *** & $\begin{array}{r}-0.486 \\
(7.85)\end{array}$ & $* * *$ & $\begin{array}{r}-0.478 \\
(7.74)\end{array}$ & $* * *$ & $\begin{array}{r}-0.662 \\
(23.87)\end{array}$ & $* * *$ & $\begin{array}{r}-1.250 \\
(11.04)\end{array}$ & *** & $\begin{array}{r}-1.252 \\
(11.05)\end{array}$ & *** \\
\hline global freedom (lagged) & $\begin{array}{l}0.192 \\
(2.38)\end{array}$ & ** & $\begin{array}{l}0.153 \\
(2.03)\end{array}$ & ** & $\begin{array}{l}0.169 \\
(2.17)\end{array}$ & ** & $\begin{array}{l}0.141 \\
(3.97)\end{array}$ & $* * *$ & $\begin{array}{l}0.167 \\
(4.36)\end{array}$ & *** & $\begin{array}{l}0.169 \\
(4.40)\end{array}$ & *** \\
\hline growth (lagged) & $\begin{array}{l}0.016 \\
(3.64)\end{array}$ & $* * *$ & $\begin{array}{l}0.015 \\
(3.33)\end{array}$ & *** & $\begin{array}{l}0.015 \\
(3.47)\end{array}$ & $* * *$ & $\begin{array}{l}0.011 \\
(4.77)\end{array}$ & $* * *$ & $\begin{array}{l}0.012 \\
(4.98)\end{array}$ & *** & $\begin{array}{l}0.012 \\
(5.04)\end{array}$ & $* * *$ \\
\hline interstate conflict (lagged) & $\begin{array}{r}-0.346 \\
(2.33)\end{array}$ & ** & $\begin{array}{r}-0.303 \\
(1.95)\end{array}$ & ** & $\begin{array}{r}-0.317 \\
(2.10)\end{array}$ & ** & $\begin{array}{r}-0.126 \\
(1.47)\end{array}$ & & $\begin{array}{r}-0.103 \\
(1.19)\end{array}$ & & $\begin{array}{r}-0.207 \\
(4.95)\end{array}$ & *** \\
\hline internal conflict (lagged) & $\begin{array}{l}0.226 \\
(2.22)\end{array}$ & ** & $\begin{array}{l}0.218 \\
(2.21)\end{array}$ & ** & $\begin{array}{l}0.218 \\
(2.20)\end{array}$ & ** & $\begin{array}{r}-0.141 \\
(2.98)\end{array}$ & $* * *$ & $\begin{array}{r}-0.243 \\
(4.91)\end{array}$ & $* * *$ & $\begin{array}{l}-0.207 \\
(4.95)\end{array}$ & *** \\
\hline $\ln (\mathrm{NPV}$ of debt/export) & $\begin{array}{l}0.131 \\
(1.91)\end{array}$ & * & $\begin{array}{l}0.116 \\
(1.78)\end{array}$ & * & $\begin{array}{l}0.121 \\
(1.82)\end{array}$ & * & $\begin{array}{l}0.182 \\
(6.43)\end{array}$ & $* * *$ & $\begin{array}{l}0.225 \\
(7.03)\end{array}$ & $* * *$ & $\begin{array}{l}0.222 \\
(6.96)\end{array}$ & *** \\
\hline $\ln$ (total ODA of donor) & $\begin{array}{r}0.990 \\
(28.16)\end{array}$ & $* * *$ & $\begin{array}{r}0.928 \\
(23.63)\end{array}$ & $* * *$ & $\begin{array}{r}0.946 \\
(26.60)\end{array}$ & $* * *$ & $\begin{array}{r}0.967 \\
(109.52)\end{array}$ & $* * *$ & $\begin{array}{r}0.964 \\
(108.96)\end{array}$ & $* * *$ & $\begin{array}{r}0.964 \\
(108.95)\end{array}$ & $* * *$ \\
\hline In(oth. donors ODA per cap) & $\begin{array}{l}0.281 \\
(4.51)\end{array}$ & $* * *$ & $\begin{array}{l}0.274 \\
(4.50)\end{array}$ & *** & $\begin{array}{l}0.273 \\
(4.48)\end{array}$ & $* * *$ & $\begin{array}{r}-0.041 \\
(1.90)\end{array}$ & * & $\begin{array}{r}-0.153 \\
(6.49)\end{array}$ & *** & $\begin{array}{r}-0.153 \\
(6.50)\end{array}$ & *** \\
\hline In(multilateral ODA per cap) & $\begin{array}{l}0.234 \\
(5.97)\end{array}$ & $* * *$ & $\begin{array}{l}0.227 \\
(6.01)\end{array}$ & *** & $\begin{array}{l}0.228 \\
(6.02)\end{array}$ & $* * *$ & $\begin{array}{r}0.204 \\
(11.13)\end{array}$ & *** & $\begin{array}{l}0.185 \\
(9.82)\end{array}$ & *** & $\begin{array}{l}0.184 \\
(9.80)\end{array}$ & *** \\
\hline In( trade) (lagged) & $\begin{array}{l}0.281 \\
(5.82)\end{array}$ & $* * *$ & $\begin{array}{l}0.265 \\
(5.74)\end{array}$ & $* * *$ & $\begin{array}{l}0.265 \\
(5.75)\end{array}$ & *** & $\begin{array}{r}0.328 \\
(35.01)\end{array}$ & *** & $\begin{array}{r}0.328 \\
(34.06)\end{array}$ & *** & $\begin{array}{r}0.328 \\
(34.05)\end{array}$ & *** \\
\hline former French colony & $\begin{array}{l}1.996 \\
(8.16)\end{array}$ & $* * *$ & $\begin{array}{l}1.946 \\
(7.98)\end{array}$ & *** & $\begin{array}{l}1.980 \\
(8.19)\end{array}$ & *** & $\begin{array}{r}1.944 \\
(20.40)\end{array}$ & *** & $\begin{array}{r}1.904 \\
(20.00)\end{array}$ & *** & $\begin{array}{r}1.904 \\
(20.00)\end{array}$ & *** \\
\hline former British colony & $\begin{array}{l}1.471 \\
(8.77)\end{array}$ & $* * *$ & $\begin{array}{l}1.373 \\
(8.41)\end{array}$ & $* * *$ & $\begin{array}{l}1.418 \\
(8.78)\end{array}$ & $* * *$ & $\begin{array}{r}1.302 \\
(16.08)\end{array}$ & *** & $\begin{array}{r}1.289 \\
(15.97)\end{array}$ & *** & $\begin{array}{r}1.289 \\
(15.97)\end{array}$ & *** \\
\hline former Portuguese colony & $\begin{array}{l}2.349 \\
(4.18)\end{array}$ & $* * *$ & $\begin{array}{l}2.400 \\
(4.59)\end{array}$ & $* \star *$ & $\begin{array}{l}2.376 \\
(4.48)\end{array}$ & $* * *$ & $\begin{array}{l}1.752 \\
(5.42)\end{array}$ & $* \star *$ & $\begin{array}{l}1.733 \\
(5.38)\end{array}$ & *** & $\begin{array}{l}1.735 \\
(5.39)\end{array}$ & *** \\
\hline former Spanish colony & $\begin{array}{r}2.801 \\
(16.82)\end{array}$ & $* * *$ & $\begin{array}{r}2.916 \\
(16.93)\end{array}$ & *** & $\begin{array}{r}2.858 \\
(18.04)\end{array}$ & *** & $\begin{array}{r}2.793 \\
(12.95)\end{array}$ & $* \star *$ & $\begin{array}{r}2.842 \\
(13.24)\end{array}$ & *** & $\begin{array}{r}2.845 \\
(13.25)\end{array}$ & $* * *$ \\
\hline former Belgium colony & $\begin{array}{r}2.714 \\
(10.23)\end{array}$ & *** & $\begin{array}{l}2.550 \\
(9.85)\end{array}$ & $* * *$ & $\begin{array}{r}2.621 \\
(10.17)\end{array}$ & $* * *$ & $\begin{array}{l}2.119 \\
(6.87)\end{array}$ & 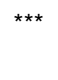 & $\begin{array}{l}2.079 \\
(6.75)\end{array}$ & *** & $\begin{array}{l}2.080 \\
(6.76)\end{array}$ & *** \\
\hline US-Egypt tie & $\begin{array}{r}3.590 \\
(35.03)\end{array}$ & $* * *$ & $\begin{array}{r}3.603 \\
(35.67)\end{array}$ & $* * *$ & $\begin{array}{r}3.615 \\
(34.89)\end{array}$ & *** & $\begin{array}{l}3.363 \\
(8.46)\end{array}$ & $* * *$ & $\begin{array}{l}3.226 \\
(8.14)\end{array}$ & *** & $\begin{array}{l}3.225 \\
(8.14)\end{array}$ & *** \\
\hline US-Latin America tie & $\begin{array}{l}0.787 \\
(2.46)\end{array}$ & ** & $\begin{array}{l}0.819 \\
(2.64)\end{array}$ & $* * *$ & $\begin{array}{l}0.813 \\
(2.59)\end{array}$ & ** & $\begin{array}{l}0.693 \\
(7.17)\end{array}$ & $* * *$ & $\begin{array}{l}0.675 \\
(7.00)\end{array}$ & *** & $\begin{array}{l}0.675 \\
(7.00)\end{array}$ & *** \\
\hline Japan-Asia tie & $\begin{array}{l}1.720 \\
(7.55)\end{array}$ & $* * *$ & $\begin{array}{l}1.732 \\
(7.68)\end{array}$ & $* * *$ & $\begin{array}{l}1.738 \\
(7.66)\end{array}$ & $* * *$ & $\begin{array}{r}1.388 \\
(12.52)\end{array}$ & $* * *$ & $\begin{array}{r}1.285 \\
(11.61)\end{array}$ & $* * *$ & $\begin{array}{r}1.285 \\
(11.61)\end{array}$ & $* * *$ \\
\hline intercept & $\begin{array}{r}-8.737 \\
(3.94) \\
\end{array}$ & *** & $\begin{array}{r}-7.495 \\
(3.39) \\
\end{array}$ & *** & $\begin{array}{r}-7.964 \\
(3.66) \\
\end{array}$ & $* * *$ & $\begin{array}{r}-2.828 \\
(4.00) \\
\end{array}$ & $* * *$ & $\begin{array}{l}7.245 \\
(3.63) \\
\end{array}$ & *** & $\begin{array}{l}7.248 \\
(3.63) \\
\end{array}$ & *** \\
\hline Number of observation & 27416 & & 33844 & & 19773 & & 19773 & & 19773 & & 19773 & \\
\hline Uncensored observations & 19773 & & 19773 & & & & & & & & & \\
\hline $\begin{array}{l}\text { Rho (Heckman model) } \\
\mathrm{R}^{2}\end{array}$ & 0.145 & $* * *$ & -0.053 & & 0.547 & & & & & & & \\
\hline $\begin{array}{l}\text { Hausman test (RE model) } \\
\text { Fisher test (FE model) }\end{array}$ & & & & & & & 251.18 & $* * *$ & 2756 & $* * *$ & 28.04 & 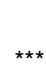 \\
\hline
\end{tabular}

(1) Standard Heckman maximum-likelihood model

(2) Heckman maximum-likelihood model without logarithm for trade, other donors' aid and multilateral aid in the selection equation

(3) OLS without sample selection correction

(4) Random-effect model

(5) Fixed-effect model

(6) Fixed-effect model with same parameter for interstate and internal t-or z-statistics between brackets (estimated with robust recipient cluster method whenever relevant) $* * *(* *, *)$ signifcant at $1 \%(5 \%, 10 \%)$ level 
Table 2: Selection equation

\begin{tabular}{|c|c|c|c|c|c|c|c|c|}
\hline \multirow[b]{2}{*}{$\ln ($ GDP per cap) (lagged) } & \multicolumn{2}{|c|}{ Probit } & \multicolumn{2}{|c|}{ Probit } & \multicolumn{2}{|c|}{$\begin{array}{l}\text { Probit with } \\
\text { random } \\
\text { recipient effect }\end{array}$} & \multicolumn{2}{|c|}{$\begin{array}{l}\text { Probit with fixed } \\
\text { recipient effects }\end{array}$} \\
\hline & $\begin{array}{r}-0.361 \\
(5.41)\end{array}$ & $* * *$ & $\begin{array}{r}-0.360 \\
(5.49)\end{array}$ & $* * *$ & $\begin{array}{r}-0.427 \\
(19.07)\end{array}$ & $* * *$ & $\begin{array}{r}-0.250 \\
(3.17)\end{array}$ & $* * *$ \\
\hline $\ln$ (population) & $\begin{array}{c}0.148 \\
(4.18)\end{array}$ & $* * *$ & $\begin{array}{r}0.152 \\
(4.38)\end{array}$ & $* * *$ & $\begin{array}{r}0.108 \\
(8.37)\end{array}$ & $* * *$ & $\begin{array}{r}0.850 \\
(9.80)\end{array}$ & $* * *$ \\
\hline global freedom (lagged) & $\begin{array}{r}0.243 \\
(3.30)\end{array}$ & $* * *$ & $\begin{array}{r}0.236 \\
(3.26)\end{array}$ & $* * *$ & $\begin{array}{r}0.123 \\
(5.26)\end{array}$ & $* * *$ & $\begin{array}{r}0.040 \\
(1.26)\end{array}$ & \\
\hline growth (lagged) & $\begin{array}{c}0.011 \\
(4.22)\end{array}$ & $* * *$ & $\begin{array}{l}0.011 \\
(4.18)\end{array}$ & $* * *$ & $\begin{array}{r}0.009 \\
(5.19)\end{array}$ & $* * *$ & $\begin{array}{r}0.007 \\
(3.89)\end{array}$ & $* * *$ \\
\hline conflict (lagged) & $\begin{array}{r}0.037 \\
(0.46)\end{array}$ & & $\begin{array}{r}0.037 \\
(0.47)\end{array}$ & & $\begin{array}{r}-0.023 \\
(0.70)\end{array}$ & & $\begin{array}{r}-0.043 \\
(1.16)\end{array}$ & \\
\hline $\ln (\mathrm{NPV}$ of debt/export) & $\begin{array}{c}0.098 \\
(2.31)\end{array}$ & $* *$ & $\begin{array}{r}0.095 \\
(2.25)\end{array}$ & $* *$ & $\begin{array}{r}0.183 \\
(12.48)\end{array}$ & $* * *$ & $\begin{array}{c}0.188 \\
(8.11)\end{array}$ & $* * *$ \\
\hline $\ln ($ total ODA of donor i) & $\begin{array}{r}0.410 \\
(23.70)\end{array}$ & $* * *$ & $\begin{array}{r}0.408 \\
(24.35)\end{array}$ & $* * *$ & $\begin{array}{r}0.431 \\
(62.60)\end{array}$ & $* * *$ & $\begin{array}{r}0.438 \\
(62.84)\end{array}$ & $* * *$ \\
\hline $\ln$ (oth. donors ODA per cap) & $\begin{array}{r}0.081 \\
(2.70)\end{array}$ & $* * *$ & $\begin{array}{r}0.084 \\
(2.83)\end{array}$ & $* * *$ & $\begin{array}{r}-0.003 \\
(0.25)\end{array}$ & & $\begin{array}{r}0.018 \\
(1.01)\end{array}$ & \\
\hline $\ln ($ multilateral ODA per cap) & $\begin{array}{l}0.065 \\
(2.48)\end{array}$ & $* * *$ & $\begin{array}{l}0.065 \\
(2.50)\end{array}$ & $* *$ & $\begin{array}{c}0.006 \\
(0.45)\end{array}$ & & $\begin{array}{l}0.022 \\
(1.59)\end{array}$ & \\
\hline $\ln ($ trade) (lagged) & $\begin{array}{c}0.136 \\
(7.09)\end{array}$ & $* * *$ & $\begin{array}{l}0.134 \\
(7.17)\end{array}$ & $* * *$ & $\begin{array}{r}0.178 \\
(28.75)\end{array}$ & $* * *$ & $\begin{array}{r}0.184 \\
(28.83)\end{array}$ & $* * *$ \\
\hline former British colony & $\begin{array}{r}1.165 \\
(5.07)\end{array}$ & $* * *$ & $\begin{array}{l}1.176 \\
(5.13)\end{array}$ & $* * *$ & $\begin{array}{r}1.106 \\
(6.85)\end{array}$ & $* * *$ & $\begin{array}{r}1.058 \\
(6.64)\end{array}$ & $* * *$ \\
\hline former Portuguese colony & $\begin{array}{r}-0.260 \\
(1.10)\end{array}$ & & & & & & & \\
\hline former Spanish colony & $\begin{array}{r}-0.479 \\
(4.73)\end{array}$ & $* * *$ & & & & & & \\
\hline US-Latin America tie & $\begin{array}{r}-0.200 \\
(0.93)\end{array}$ & & & & & & & \\
\hline intercept & $\begin{array}{r}-6.332 \\
(5.78)\end{array}$ & & $\begin{array}{l}-6.392 \\
(5.95)\end{array}$ & $* * *$ & $\begin{array}{r}-5.135 \\
(13.82)\end{array}$ & $* * *$ & recipient spe & cific \\
\hline Number of observations & 26739 & & 26739 & & 26739 & & 26739 & \\
\hline Pseudo R2 & 0.233 & & 0.233 & & & & 0.287 & \\
\hline
\end{tabular}

Note: When the dummy variables for former French, Portuguese or Spanish colonies and for the US-Egypt and Japan-Asia ties are equal to 1 , selection is perfectly predicted, which prevents estimating properly the corresponding parameters. The 1155 corresponding observations are dropped.

The Probit with fixed effect is reported only for illustration. 
Tableau 3: Clustering donor countries

\begin{tabular}{|c|c|c|c|c|c|c|}
\hline Donor country & $\begin{array}{l}\text { Elasticity o } \\
\text { to trade inte }\end{array}$ & $\begin{array}{l}\text { f aid } \\
\text { ensity }\end{array}$ & $\begin{array}{r}\text { Differen } \\
\text { average ot }\end{array}$ & $\begin{array}{l}\text { ce with } \\
\text { her donor }\end{array}$ & Category & Selflessness rank \\
\hline Australia & $\begin{array}{r}0.725 \\
(24.74)\end{array}$ & $* * *$ & $\begin{array}{r}0.420 \\
(5.79)\end{array}$ & $* * *$ & selfish & 17 \\
\hline Austria & $\begin{array}{r}0.193 \\
(4.83)\end{array}$ & $* * *$ & $\begin{array}{l}-0.127 \\
(2.86)\end{array}$ & $* * *$ & altruistic & 6 \\
\hline Belgium & $\begin{array}{l}0.309 \\
(9.02)\end{array}$ & $* * *$ & $\begin{array}{r}-0.032 \\
(0.82)\end{array}$ & & average & 11 \\
\hline Canada & $\begin{array}{r}0.309 \\
(9.73)\end{array}$ & $* * *$ & $\begin{array}{r}-0.027 \\
(0.75)\end{array}$ & & average & 12 \\
\hline Denmark & $\begin{array}{r}0.144 \\
(2.39)\end{array}$ & $* *$ & $\begin{array}{l}-0.187 \\
(2.81)\end{array}$ & $* * *$ & altruistic & 3 \\
\hline Finland & $\begin{array}{r}0.272 \\
(7.88)\end{array}$ & $* * *$ & $\begin{array}{r}-0.059 \\
(1.52)\end{array}$ & & average & 9 \\
\hline France & $\begin{array}{r}0.505 \\
(14.84)\end{array}$ & $* * *$ & $\begin{array}{l}0.202 \\
(5.40)\end{array}$ & $* * *$ & selfish & 16 \\
\hline Germany & $\begin{array}{r}0.254 \\
(6.54)\end{array}$ & $* * *$ & $\begin{array}{r}-0.058 \\
(1.37)\end{array}$ & & average & 10 \\
\hline Ireland & $\begin{array}{r}0.122 \\
(2.95)\end{array}$ & $* * *$ & $\begin{array}{r}-0.213 \\
(4.62)\end{array}$ & $* * *$ & altruistic & 2 \\
\hline Italy & $\begin{array}{r}0.498 \\
(12.85)\end{array}$ & $* * *$ & $\begin{array}{l}0.189 \\
(4.41)\end{array}$ & $* * *$ & selfish & 15 \\
\hline Japan & $\begin{array}{r}0.318 \\
(9.75)\end{array}$ & $* * *$ & $\begin{array}{l}0.000 \\
(0.00)\end{array}$ & & average & 13 \\
\hline Japan $^{(\mathrm{a})}$ & $\begin{array}{r}0.401 \\
(12.66)\end{array}$ & $* * *$ & $\begin{array}{l}0.069 \\
(1.95)\end{array}$ & $*$ & selfish & \\
\hline Netherlands & $\begin{array}{r}0.184 \\
(4.88)\end{array}$ & $* * *$ & $\begin{array}{r}-0.143 \\
(3.44)\end{array}$ & $* * *$ & altruistic & 5 \\
\hline New Zealand & $\begin{array}{r}0.279 \\
(6.93)\end{array}$ & $* * *$ & $\begin{array}{r}-0.071 \\
(1.57)\end{array}$ & & average & 7 \\
\hline Norway & $\begin{array}{r}0.183 \\
(5.80)\end{array}$ & $* * *$ & $\begin{array}{r}-0.152 \\
(4.25)\end{array}$ & $* * *$ & altruistic & 4 \\
\hline Switzerland & $\begin{array}{r}-0.055 \\
(1.34)\end{array}$ & & $\begin{array}{r}-0.390 \\
(8.68)\end{array}$ & $* * *$ & altruistic & 1 \\
\hline United Kingdom & $\begin{array}{r}0.465 \\
(10.25)\end{array}$ & $* * *$ & $\begin{array}{l}0.158 \\
(3.20)\end{array}$ & $* * *$ & selfish & 14 \\
\hline United States & $\begin{array}{r}0.277 \\
(6.76)\end{array}$ & $* * *$ & $\begin{array}{r}-0.061 \\
(1.34)\end{array}$ & & average & 8 \\
\hline United States $^{(b)}$ & $\begin{array}{r}0.386 \\
(10.40)\end{array}$ & & $\begin{array}{l}0.066 \\
(1.59)\end{array}$ & & average & \\
\hline
\end{tabular}

Notes:

- the elasticity estimates come from a fixed-effect regression with donor-specific parameters estimated together

- the difference with average donor comes from fixed-effect regression with common parameters for all the other donors than the specified donor

- (a) models estimated without the Japan - Asia dummy variable

- (b) models estimated without the United States - Latin America dummy variable 
Table 4: Comparison of parameters for donor in « altruistic » cluster

\begin{tabular}{|c|c|c|c|c|c|c|c|c|c|c|c|c|c|c|c|c|c|c|}
\hline \multirow{2}{*}{$\begin{array}{l}\text { donor } \\
\ln \text { (GDP per cap) } \\
\text { (lagged) }\end{array}$} & \multicolumn{3}{|c|}{ Austria } & \multicolumn{3}{|c|}{ Denmark } & \multicolumn{3}{|c|}{ Ireland } & \multicolumn{3}{|c|}{ Netherlands } & \multicolumn{3}{|c|}{ Norway } & \multicolumn{3}{|c|}{ Switzerland } \\
\hline & -0.135 & & $>$ & -0.903 & $* * *$ & & -1.237 & $* * *$ & $<$ & -0.941 & $* * *$ & $<$ & -1.233 & $* * *$ & $<$ & -0.851 & $* * *$ & \\
\hline $\ln$ (population) & -1.115 & $* * *$ & & -1.178 & $* * *$ & & -1.795 & $* * *$ & $<$ & -0.991 & $* * *$ & $>$ & -1.129 & $* * *$ & $>$ & -1.000 & $* * *$ & $>$ \\
\hline $\begin{array}{l}\text { global freedom } \\
\text { (lagged) }\end{array}$ & -0.759 & $* * *$ & $<$ & 0.193 & & & -0.089 & & & 0.466 & $* * *$ & $>$ & 0.201 & $*$ & & 0.093 & & \\
\hline $\begin{array}{l}\text { growth } \\
\text { (lagged) }\end{array}$ & 0.026 & $* * *$ & & 0.038 & $* * *$ & & 0.000 & & & -0.004 & & $<$ & 0.016 & $*$ & & 0.009 & & \\
\hline $\begin{array}{l}\text { Conflict } \\
\text { (lagged) }\end{array}$ & 0.199 & $*$ & $>$ & -0.339 & $* *$ & & -0.323 & $* *$ & & 0.116 & $>$ & & 0.225 & $*$ & $>$ & 0.123 & & $>$ \\
\hline $\begin{array}{l}\ln (\mathrm{NPV} \text { of } \\
\text { debt/export) }\end{array}$ & 0.313 & $* * *$ & & -0.044 & & $<$ & 0.207 & $* *$ & & 0.235 & $* * *$ & & -0.128 & & $<$ & 0.120 & $*$ & \\
\hline $\begin{array}{l}\text { ln (total aid of } \\
\text { donor i) }\end{array}$ & 0.581 & $* * *$ & $<$ & 1.305 & $* * *$ & & 0.683 & $* * *$ & $<$ & 0.946 & $* * *$ & & 0.133 & & $<$ & 0.664 & $* * *$ & \\
\hline $\begin{array}{l}\ln \text { (oth. Donors } \\
\text { aid per capita) }\end{array}$ & -0.088 & & & 0.042 & & & -0.510 & $* * *$ & $<$ & 0.134 & $* *$ & $>$ & -0.014 & & & -0.084 & & \\
\hline $\begin{array}{l}\ln \text { (multilateral } \\
\text { aid per cap) }\end{array}$ & 0.049 & & $<$ & 0.201 & $* *$ & & 0.039 & & & 0.189 & $* * *$ & & 0.257 & $* * *$ & & 0.192 & $* * *$ & \\
\hline $\begin{array}{l}\ln (\text { trade }) \\
\text { lagged }\end{array}$ & 0.193 & $* * *$ & $<$ & 0.144 & $* *$ & $<$ & 0.122 & $* * *$ & $<$ & 0.184 & $* * *$ & $<$ & 0.183 & $* * *$ & $<$ & -0.055 & & $<$ \\
\hline
\end{tabular}

Note: $* * *(* *, *)$ means significant at $1 \%(5 \%, 10 \%)$ level

$>$ means a significantly higher parameter than the other donors (at $5 \%$ level)

$<$ means a significantly lower parameter than the other donors (at 5\% level)

Estimation method: see note of Table ...

Table 5: Comparison of parameters for donor in « average » cluster

\begin{tabular}{|c|c|c|c|c|c|c|c|c|c|c|c|c|c|c|c|c|c|c|c|c|c|}
\hline \multirow{2}{*}{$\begin{array}{l}\text { donor } \\
\ln (\text { GDP per } \\
\text { cap) (lagged) }\end{array}$} & \multicolumn{3}{|c|}{ Belgium } & \multicolumn{3}{|c|}{ Canada } & \multicolumn{3}{|c|}{ Finland } & \multicolumn{3}{|c|}{ Germany } & \multicolumn{3}{|c|}{ Japan } & \multicolumn{3}{|c|}{ New Zealand } & \multicolumn{3}{|c|}{ United States } \\
\hline & -0.551 & $* * *$ & $>$ & -0.694 & $* * *$ & & -0.749 & $* * *$ & & -0.467 & $* * *$ & $>$ & -0.228 & $>$ & & -1.011 & $* * *$ & & -1.090 & $* * *$ & $<$ \\
\hline $\ln$ (population) & -1.263 & $* * *$ & & -1.014 & $* * *$ & $>$ & -1.264 & $* * *$ & & -0.899 & $* * *$ & $>$ & -1.073 & $* * *$ & $>$ & -1.850 & $* * *$ & $<$ & -1.166 & $* * *$ & $>$ \\
\hline $\begin{array}{l}\text { global freedom } \\
\text { (lagged) }\end{array}$ & -0.112 & & $<$ & 0.226 & & & 0.022 & & & -0.007 & & & 0.423 & & $>$ & 0.352 & & & 0.155 & & \\
\hline $\begin{array}{l}\text { growth } \\
\text { (lagged) }\end{array}$ & -0.016 & $*$ & $<$ & -0.005 & & $<$ & 0.015 & & & -0.005 & & $<$ & 0.022 & $* * *$ & & 0.009 & & & -0.008 & & $<$ \\
\hline $\begin{array}{l}\text { Conflict } \\
\text { (lagged) }\end{array}$ & -0.546 & $* * *$ & $<$ & -0.258 & $* *$ & & 0.031 & & & -0.501 & $* * *$ & $<$ & -0.873 & $* * *$ & $<$ & -0.200 & & & 0.421 & $* * *$ & $>$ \\
\hline $\begin{array}{l}\ln (\mathrm{NPV} \text { of } \\
\text { debt/export) }\end{array}$ & 0.293 & $* * *$ & & 0.077 & & & 0.185 & $* *$ & & 0.252 & $* * *$ & & 0.317 & $* * *$ & $>$ & -0.381 & $* * *$ & $<$ & -0.041 & & $<$ \\
\hline $\begin{array}{l}\ln (\text { total aid of } \\
\text { donor i) }\end{array}$ & 0.584 & $* * *$ & & 0.773 & $* * *$ & & 0.688 & $* * *$ & $<$ & 0.867 & $* * *$ & & 1.116 & $* * *$ & & 0.521 & $*$ & & 0.686 & $* * *$ & $<$ \\
\hline $\begin{array}{l}\ln \text { (oth. Donors } \\
\text { aid per capita) }\end{array}$ & 0.164 & $* *$ & $>$ & 0.100 & $*$ & $>$ & 0.190 & $* *$ & $>$ & 0.058 & & $>$ & -0.114 & $* *$ & & 0.245 & $* *$ & $>$ & 0.056 & & $>$ \\
\hline $\begin{array}{l}\ln \text { (multilateral } \\
\text { aid per cap) }\end{array}$ & -0.083 & & $<$ & 0.283 & $* * *$ & & 0.166 & $* *$ & & 0.118 & $* *$ & & 0.223 & $* * *$ & & -0.431 & $* * *$ & $<$ & 0.359 & $* * *$ & $>$ \\
\hline $\begin{array}{l}\ln (\text { trade }) \\
\text { lagged }\end{array}$ & 0.309 & $* * *$ & & 0.309 & $* * *$ & & 0.272 & $* * *$ & & 0.254 & $* * *$ & & 0.318 & $* * *$ & & 0.279 & $* * *$ & & 0.277 & $* * *$ & \\
\hline
\end{tabular}


Table 6: Comparison of parameters for donor in « egoistic » cluster

\begin{tabular}{|c|c|c|c|c|c|c|c|c|c|c|c|c|}
\hline \multirow{2}{*}{$\begin{array}{l}\text { donor } \\
\ln (\text { GDP per } \\
\text { cap) (lagged) }\end{array}$} & \multicolumn{3}{|c|}{ Australia } & \multicolumn{3}{|c|}{ France } & \multicolumn{3}{|c|}{ Italy } & \multicolumn{3}{|c|}{ United Kingdom } \\
\hline & -1.607 & $* * *$ & $<$ & -0.433 & $* * *$ & $>$ & -0.899 & $* * *$ & & -0.828 & $* * *$ & \\
\hline $\ln$ (population) & -1.938 & $* * *$ & $<$ & -1.390 & $* * *$ & $<$ & -1.559 & $* * *$ & $<$ & -1.295 & $* * *$ & \\
\hline $\begin{array}{l}\text { Conflict } \\
\text { (lagged) }\end{array}$ & -0.004 & & & -0.428 & $* * *$ & $<$ & -0.024 & & & -0.244 & $* *$ & \\
\hline $\begin{array}{l}\ln (\mathrm{NPV} \text { of } \\
\text { debt/export) }\end{array}$ & -0.367 & $* * *$ & $<$ & 0.458 & $* * *$ & $>$ & 0.844 & $* * *$ & $>$ & -0.030 & & $<$ \\
\hline $\begin{array}{l}\text { global freedom } \\
\text { (lagged) }\end{array}$ & 0.312 & $* *$ & & 0.265 & $* * *$ & & 0.235 & $* *$ & & 0.411 & $* * *$ & $>$ \\
\hline $\begin{array}{l}\text { growth } \\
\text { (lagged) }\end{array}$ & 0.059 & & $>$ & 0.031 & & $>$ & 0.008 & & & 0.021 & & \\
\hline $\begin{array}{l}\text { In (total aid of } \\
\text { donor i) }\end{array}$ & 0.454 & $* *$ & $<$ & 0.719 & $* * *$ & & 1.160 & $* * *$ & $>$ & 0.655 & $* * *$ & \\
\hline $\begin{array}{l}\ln \text { (oth. Donors } \\
\text { aid per capita) }\end{array}$ & -0.123 & $*$ & & -0.220 & $* * *$ & $<$ & -0.098 & $*$ & & -0.243 & $* * *$ & $<$ \\
\hline $\begin{array}{l}\ln \text { (multilateral } \\
\text { aid per cap) }\end{array}$ & 0.194 & $* * *$ & & 0.117 & $* *$ & & 0.071 & & $<$ & 0.189 & $* * *$ & \\
\hline $\begin{array}{l}\ln (\text { trade }) \\
\text { lagged }\end{array}$ & 0.725 & $* * *$ & $>$ & 0.505 & $* * *$ & $>$ & 0.498 & $* * *$ & $>$ & 0.465 & $* * *$ & $>$ \\
\hline
\end{tabular}


Table 7: Comparison of parameters estimated for the 1980s and the 1990s

\begin{tabular}{|c|c|c|c|c|c|c|}
\hline & $1990 \mathrm{~s}$ & & $1980 \mathrm{~s}$ & & $1990 \mathrm{~s}-1980 \mathrm{~s}$ & \\
\hline $\ln$ (GDP per cap) (lagged) & $\begin{array}{r}-0.871 \\
(7.85)\end{array}$ & $* * *$ & $\begin{array}{c}-0.957 \\
(7.93)\end{array}$ & $* * *$ & $\begin{array}{l}0.087 \\
(1.54)\end{array}$ & \\
\hline $\ln$ (population) & $\begin{array}{r}-1.151 \\
(6.07)\end{array}$ & $* * *$ & $\begin{array}{r}-1.220 \\
(6.46)\end{array}$ & $* * *$ & $\begin{array}{l}0.069 \\
(2.31)\end{array}$ & $* *$ \\
\hline global freedom $<=4$ (lagged) & $\begin{array}{r}0.189 \\
(3.98)\end{array}$ & $* * *$ & $\begin{array}{c}0.181 \\
(3.48)\end{array}$ & $* * *$ & $\begin{array}{c}0.008 \\
(0.14)\end{array}$ & \\
\hline growth (lagged) & $\begin{array}{r}0.013 \\
(4.24)\end{array}$ & $* * *$ & $\begin{array}{l}0.010 \\
(2.69)\end{array}$ & $* * *$ & $\begin{array}{c}0.003 \\
(0.66)\end{array}$ & \\
\hline conflicts (lagged) & $\begin{array}{r}-0.157 \\
(3.04)\end{array}$ & $* * *$ & $\begin{array}{r}-0.260 \\
(4.79)\end{array}$ & $* * *$ & $\begin{array}{c}0.103 \\
(1.59)\end{array}$ & \\
\hline $\ln (\mathrm{NPV}$ of debt/export) & $\begin{array}{l}0.195 \\
(4.77)\end{array}$ & $* * *$ & $\begin{array}{c}0.244 \\
(6.81)\end{array}$ & $* * *$ & $\begin{array}{r}-0.049 \\
(1.28)\end{array}$ & \\
\hline $\ln ($ total ODA of donor i) & $\begin{array}{r}0.946 \\
(76.91)\end{array}$ & $* * *$ & $\begin{array}{r}0.982 \\
(77.72)\end{array}$ & $* * *$ & $\begin{array}{r}-0.036 \\
(2.05)\end{array}$ & $* *$ \\
\hline $\ln$ (oth. donors ODA per cap) & $\begin{array}{r}-0.131 \\
(4.66)\end{array}$ & $* * *$ & $\begin{array}{r}-0.188 \\
(6.35)\end{array}$ & $* * *$ & $\begin{array}{l}0.057 \\
(1.77)\end{array}$ & * \\
\hline $\ln$ (multilateral ODA per cap) & $\begin{array}{r}0.151 \\
(6.44)\end{array}$ & $* * *$ & $\begin{array}{l}0.245 \\
(9.14)\end{array}$ & $* * *$ & $\begin{array}{r}-0.094 \\
(2.98)\end{array}$ & $* * *$ \\
\hline $\ln ($ trade) (lagged) & $\begin{array}{r}0.278 \\
(21.56)\end{array}$ & $* * *$ & $\begin{array}{r}0.378 \\
(29.28)\end{array}$ & $* * *$ & $\begin{array}{r}-0.100 \\
(5.83)\end{array}$ & $* * *$ \\
\hline former French colony & $\begin{array}{r}2.046 \\
(15.28)\end{array}$ & $* * *$ & $\begin{array}{r}1.759 \\
(13.49)\end{array}$ & $* * *$ & $\begin{array}{l}0.287 \\
(1.57)\end{array}$ & \\
\hline former British colony & $\begin{array}{r}1.463 \\
(12.62)\end{array}$ & $* * *$ & $\begin{array}{r}1.123 \\
(10.19)\end{array}$ & $* * *$ & $\begin{array}{l}0.339 \\
(2.14)\end{array}$ & $* *$ \\
\hline former Portuguese colony & $\begin{array}{r}1.924 \\
(5.93)\end{array}$ & $* * *$ & & & & \\
\hline former Spanish colony & $\begin{array}{r}2.860 \\
(13.29)\end{array}$ & & & & & \\
\hline former Belgium colony & $\begin{array}{l}2.112 \\
(5.08)\end{array}$ & $* * *$ & $\begin{array}{r}2.090 \\
(4.74)\end{array}$ & $* * *$ & $\begin{array}{c}0.022 \\
(0.00)\end{array}$ & \\
\hline US-Egypt tie & $\begin{array}{l}3.369 \\
(5.95)\end{array}$ & $* * *$ & $\begin{array}{r}3.078 \\
(5.72)\end{array}$ & $* * *$ & $\begin{array}{l}0.291 \\
(0.37)\end{array}$ & \\
\hline US-Latin America tie & $\begin{array}{r}0.648 \\
(4.86)\end{array}$ & $* * *$ & $\begin{array}{c}0.707 \\
(5.17)\end{array}$ & $* * *$ & $\begin{array}{r}-0.060 \\
(0.32)\end{array}$ & \\
\hline Japan-Asia tie & $\begin{array}{l}1.527 \\
(9.70)\end{array}$ & $* * *$ & $\begin{array}{r}1.055 \\
(6.99)\end{array}$ & $* * *$ & $\begin{array}{l}0.473 \\
(2.20)\end{array}$ & $* *$ \\
\hline intercept & $\begin{array}{r}6.219 \\
(1.85) \\
\end{array}$ & $*$ & $\begin{array}{r}8.191 \\
(2.50) \\
\end{array}$ & $* *$ & $\begin{array}{r}-1.972 \\
-(2.02)\end{array}$ & $* *$ \\
\hline Number of observations & 9580 & & 10193 & & & \\
\hline
\end{tabular}

Note: All parameter are estimated in a single fixed effect model with different sets of parameters for the two decades 
Table 8: Grant allocation equation

\begin{tabular}{|c|c|c|c|c|c|c|c|c|}
\hline \multirow[b]{2}{*}{$\ln$ (GDP per cap) (lagged) } & \multicolumn{2}{|c|}{ whole period } & \multicolumn{2}{|l|}{$1990 \mathrm{~s}$} & \multicolumn{2}{|l|}{$1980 \mathrm{~s}$} & \multicolumn{2}{|c|}{ 1990s-1980s } \\
\hline & -0.820 & $* * *$ & -0.869 & $* * *$ & -1.057 & $* * *$ & 0.188 & $* * *$ \\
\hline & $-(8.61)$ & & $(8.15)$ & & $(9.08)$ & & $(3.42)$ & \\
\hline \multirow[t]{2}{*}{$\ln ($ population) } & -1.468 & $* * *$ & -1.197 & $* * *$ & -1.331 & $* * *$ & 0.134 & $* * *$ \\
\hline & $-(13.70)$ & & $(6.63)$ & & (7.41) & & $(4.36)$ & \\
\hline \multirow[t]{2}{*}{ global freedom (lagged) } & 0.192 & $* * *$ & 0.176 & $* * *$ & 0.258 & $* * *$ & -0.082 & \\
\hline & $(5.19)$ & & $(3.86)$ & & (5.13) & & $(1.39)$ & \\
\hline growth (lagged) & 0.010 & $* * *$ & 0.011 & $* * *$ & 0.009 & ** & 0.003 & \\
\hline \multirow[t]{2}{*}{ conflict (lagged) } & -0.168 & $* * *$ & -0.117 & $* *$ & -0.218 & $* * *$ & 0.101 & \\
\hline & (4.19) & & $(2.36)$ & & (4.19) & & $(1.62)$ & \\
\hline \multirow[t]{3}{*}{$\ln (\mathrm{NPV}$ of debt/export) } & 0.218 & $* * *$ & 0.194 & $* * *$ & 0.242 & $* * *$ & -0.048 & \\
\hline & $(7.06)$ & & $(4.93)$ & & (6.98) & & $(1.30)$ & \\
\hline & $(4.60)$ & & $(3.89)$ & & $(2.53)$ & & $(0.56)$ & \\
\hline \multirow[t]{2}{*}{$\ln ($ total grants of donor i) } & 1.003 & $* * *$ & 1.030 & $* * *$ & 0.976 & $* * *$ & 0.053 & ** \\
\hline & (109.09) & & $(79.04)$ & & (75.46) & & (2.91) & \\
\hline \multirow[t]{2}{*}{$\ln$ (oth. donors grants per cap) } & -0.284 & $* * *$ & -0.234 & $* * *$ & -0.343 & $* * *$ & 0.110 & $* * *$ \\
\hline & $-(10.97)$ & & $(7.20)$ & & $(11.06)$ & & $(2.91)$ & \\
\hline \multirow[t]{2}{*}{$\ln ($ multilateral ODA per cap) } & 0.202 & $* * *$ & 0.176 & $* * *$ & 0.238 & $* * *$ & -0.062 & $* *$ \\
\hline & $(11.20)$ & & (7.76) & & $(9.36)$ & & $(2.01)$ & \\
\hline \multirow[t]{2}{*}{$\ln ($ trade $)$ (lagged) } & 0.306 & $* * *$ & 0.258 & $* * *$ & 0.356 & $* * *$ & -0.099 & $* * *$ \\
\hline & $(33.27)$ & & $(21.01)$ & & $(28.75)$ & & $(6.03)$ & \\
\hline \multirow[t]{2}{*}{ former French colony } & 1.849 & $* * *$ & 1.951 & $* * *$ & 1.734 & $* * *$ & 0.216 & \\
\hline & $(20.31)$ & & $(15.21)$ & & $(13.93)$ & & $(1.23)$ & \\
\hline \multirow[t]{2}{*}{ former British colony } & 1.045 & $* * *$ & 1.222 & $* * *$ & 0.886 & $* * *$ & 0.336 & $* *$ \\
\hline & (13.13) & & $(10.35)$ & & $(8.37)$ & & $(2.14)$ & \\
\hline \multirow[t]{2}{*}{ former Portuguese colony } & 1.861 & $* * *$ & 2.154 & $* * *$ & & & & \\
\hline & $(5.93)$ & & $(6.81)$ & & & & & \\
\hline \multirow[t]{2}{*}{ former Spanish colony } & 2.467 & $* * *$ & 2.518 & $* * *$ & & & & \\
\hline & $(9.90)$ & & $(10.10)$ & & & & & \\
\hline \multirow[t]{2}{*}{ former Belgium colony } & 2.024 & $* * *$ & 2.080 & $* * *$ & 2.007 & $* * *$ & 0.073 & \\
\hline & $(6.86)$ & & $(5.23)$ & & $(4.75)$ & & $(0.14)$ & \\
\hline \multirow[t]{2}{*}{ US-Egypt tie } & 2.917 & $* * *$ & 2.944 & $* * *$ & 2.860 & $* * *$ & 0.085 & \\
\hline & $(7.66)$ & & (5.43) & & $(5.53)$ & & $(0.10)$ & \\
\hline \multirow[t]{2}{*}{ US-Latin America tie } & 0.328 & $* * *$ & 0.341 & $* * *$ & 0.323 & $* *$ & 0.018 & \\
\hline & $(3.52)$ & & (2.66) & & (2.44) & & $(0.10)$ & \\
\hline \multirow[t]{2}{*}{ Japan-Asia tie } & 1.458 & $* * *$ & 1.617 & $* * *$ & 1.287 & $* * *$ & 0.330 & \\
\hline & $(14.00)$ & & $(10.90)$ & & $(9.04)$ & & $(1.62)$ & \\
\hline \multirow[t]{2}{*}{ intercept } & 10.469 & $* * *$ & 5.364 & * & 11.037 & $* * *$ & -5.673 & $* * *$ \\
\hline & $(5.51)$ & & $(1.67)$ & & $(3.54)$ & & $(5.71)$ & \\
\hline Number of observations & 19640 & & 10136 & & 9504 & & & \\
\hline
\end{tabular}

Note: All estimates are done with fixed effect model. Parameters for the 1990s and 1980s decades are estimated in a single equation with different sets of parameters for the two decades. 